\title{
Morphological characterization of garlic (Allium sativum L.) germplasm
}

\author{
Md. Salahuddin" ${ }^{*}$, M.A. Rahim¹, S.M.Jakir Bin Alam², Md. Mahfujur Rahman³ , Jubaidur Rahman ${ }^{4}$
}

${ }^{1}$ The Department of Horticulture, Bangladesh Agricultural University, Mymensingh-2202, Bangladesh

${ }^{2}$ The Department of Environmental Science, Bangladesh Agricultural University, Mymensingh-2202, Bangladesh

${ }^{3}$ The Department of Entomology, Bangladesh Agricultural University, Mymensingh-2202, Bangladesh

${ }^{4}$ Scientific Officer, Agronomy Division, Bangladesh Agricultural Research Institute, Jamalpur-2000, Bangladesh

*Corresponding Author Email: salahuddin.at@gmail.com

\section{Doi: $10.2478 / \mathrm{mjhr}-2019-0014$}

\section{Abstract:}

A total of 25 garlic (Allium sativum L.) germplasm were collected from different location of Bangladesh and also from different countries of the world. Each germplasm was planted in each plot of $1 \mathrm{~m} 2$ at the Allium Field Laboratory, Horticulture Farm, Bangladesh Agricultural University, Mymensingh. This study was conducted during October, 2010 to March, 2011 in the field, using randomized complete block design with three replications. All germplasm were characterized on number of leaves, height of plant, leaf length, fresh weight of leaf, dry weight of leaf, number of cloves per bulb, length and diameter of bulb, fresh weight of bulb, dry weight of bulb, yield per plot and yield per hectare. Analyses of variances showed that garlic germplasm with different origins were significantly different for all characters. Different germplasm resulted better performances but germplasm G49 from Vietnam gave the highest results in respect of number of leaves per plant (10.63), leaf length (43.57 cm), fresh leaf weight (92.47g), dry leaf weight (6.13g), fresh weight of bulb (21.37g), total number of cloves per bulb (42.13), bulb diameter $(4.13 \mathrm{~cm})$, fresh weight of bulb (21.37g), dry weight of bulb (5.73g) and yield (9.83 t/ha) which could help future researchers in garlic selection program and improvement of yield.

Keywords: Characterization, Germplasm, Garlic (Allium sativum L.)

\subsection{Introduction:}

Allium sativum, commonly known as garlic, is a species of the onion family Alliaceae. Its close relatives include the onion, shallot and leek. It is the second most widely used spice crop of the cultivated Allium crops, next to onion in the world [1]. Its primary center of origin is Central Asia (Kazakhstan), and the secondary center is the Mediterranean and Caucasus zones. The area under garlic cultivation in Bangladesh is only 38.86 thousand hectares and the production is 177 thousand metric tons [2]. Garlic is important for its culinary and medicinal importance throughout the world. The cloves are used for consumption (raw or cooked), or for medicinal purposes, and have a characteristic pungent, spicy flavor that mellows and sw eetens considerably with cooking. Today garlic is used to help in preventing heart disease, including atherosclerosis (plaque buildup in the arteries that can block the flow of blood and possibly lead to heart attack or stroke), high cholesterol, high blood pressure, and to improve the immune system. Garlic may also protect against cancer. The world average yield of garlic is $11.99 \mathrm{t} / \mathrm{ha}$ [3]. On the other hand the yield in Bangladesh is only $2.86 \mathrm{t} / \mathrm{ha}$, which is very low compared to the yield of many other countries [3-9]. In Bangladesh, the requirement of garlic is about 219 thousand metric tons, and the deficit is around 42 thousand metric tons. In spite of high demand, Bangladesh is not in a position to supply and fulfill the actual demand for garlic. The major reasons behind this are lack of suitable genotypes, lack of land, use of local unimproved varieties, environmental stress, poor crop management, proper research and lack of knowledge about the morphological characteristics of garlic germplasm. A good number of landraces of garlic are present in Bangladesh [10-15]. But till now few recommended or released varieties are available. Systematic research was not conducted in the past to evaluate potentialities of the available garlic germplasm. Knowledge about the morphological characteristics of garlic germplasm is most important for selection of the appropriate varieties for appropriate place and achievement of high yield. Besides, characterization is an important aspect for documentation of the performance of the studied cultivars, which subsequently will help to introduce, select and improve the existing varieties [16-19]. The present experiment has been taken to determine the morphological characteristics of 25 garlic germplasm and to evaluate the comparative performance of the selected germplasm.

\subsection{Materials and methods}

The research work was done in the rabi season during October 2010 to March 2011 at the Allium Field Laboratory, Horticulture Farm, Bangladesh Agricultural University, Mymensingh. Materials used and methodologies followed in this investigation have been described below:

\subsection{Study materials}

Twenty five germplasm of garlic were collected from different parts of Bangladesh (Nilphamari, Dinajpur, Ishurdi, Magura, Rajshahi and Mymensingh district) also different parts of the world (Tunisia, Turkey, Florida, China and Vietnam). The details of germplasm are listed in Table 1.

Table 1: List of 25 garlic germplasm used in the study

\begin{tabular}{|c|c|c|c|}
\hline Sl. No. & Germplasm & Local Name & Collected from \\
\hline 1 & G1 & BAU Garlic -1 & BAU- Mymensing \\
\hline 2 & G 2 & BAU Garlic -2 & BAU- Mymensing \\
\hline 3 & G3 & Baserhati & Baserhat, Dinajpur \\
\hline 4 & G5 & Lal Shil & Domar, Nilphamari \\
\hline 5 & G8 8 & Mahakunda & Dadpur, Pabna \\
\hline 6 & G10 & Sada shil & Sadar, Nilphamari \\
\hline 7 & G13 & Lal Shil & Dimla, Nilphamari \\
\hline 8 & G15 & Sutna & Mohonpur, Rajshahi \\
\hline 9 & G19 & BAU Selection-1 & BAU- Mymensing \\
\hline 10 & G20 & Sada shil & Debigonj,Panchagarh \\
\hline 11 & G27 & Florida -1 & Florida, USA \\
\hline
\end{tabular}




\begin{tabular}{|c|c|c|c|}
\hline 12 & G28 & Florida -2 & Florida, USA \\
\hline 13 & G29 & Turkey-1 & Turkey \\
\hline 14 & G30 & Turkey -2 & Turkey \\
\hline 15 & G31 & Tunisia -1 & Tunisia \\
\hline 16 & G32 & Tunisia -2 & Tunisia \\
\hline 17 & G33 & Tunisia -3 & Tunisia \\
\hline 18 & G35 & China -1 & China \\
\hline 19 & G36 & China -2 & China \\
\hline 20 & G37 & China -3 & China \\
\hline 21 & G38 & China -4 & China \\
\hline 22 & G49 & Vietnam-2009 & Vietnam \\
\hline 23 & G51 & Putia-10 & Putia, Rajshahi \\
\hline 24 & G52 & China -10 & China \\
\hline 25 & G53 & Vietnam-2010 & Vietnam \\
\hline
\end{tabular}

\subsection{Methods}

\subsubsection{Climate and Soil condition}

The experimental area was under a sub-tropical humid climate which is characterized by heavy rainfall, air temperature, sunshine hour, annual average rainfall and relative humidity and have been presented in Appendix I. The soil of the experimental area of Bangladesh Agricultural University Farm was sandy loam and belongs to the Old-Brahmaputra Flood-Plain Alluvial Tract [4]. The soil samples collected at a depth of 0-30 cm from the, experimental area were analyzed in the Humboldt Soil Testing Laboratory, Department of Soil Science, Bangladesh Agricultural University, Mymensingh. Description of the characteristics of soil of the experimental plot have been presented in Appendix II [20-25]. The morphological characteristics of the soil of the experimental plot are given below [3].

AEZ: Old Brahmaptura Flood Plain

Soil series: Sonatala series

General soil: Non calcareous dark grey

Parent material: Old Brahmaptura River-borne deposits.

\subsubsection{Cultural management}

\subsubsection{Land preparation}

The experimental land was first opened by tractor one month before planting. Several ploughing and cross ploughing followed by laddering were done until the desired tilth was achieved for planting the cloves. Weeds and stubbles were then removed from the field. Finally, the land was divided into blocks in which small plots (plot size were mentioned in individual experiment) were made as an experimental unit according to the design of the experiment.

\subsubsection{Manure and fertilizer}

The crop received manures and fertilizers at the rate of cowdung 5 tons, Urea $217 \mathrm{~kg}$, T.S.P. $267 \mathrm{~kg}$, M.P. $333 \mathrm{~kg}$ and Zypsum $111 \mathrm{~kg}$ per hectare respectively [26-29]. The entire amount of cowdung and TSP were added to the soil at the time of final land preparation 7 days before planting. Urea and MP were top dressed in three equal installments at 25,50 and 75 days after planting of cloves or transplanting of seedlings.

\subsubsection{Planting materials}

Cloves were separated from the bulb, and only the healthy large sized ones were planted.

Date of planting: 10 Nov, 2010

Plant spacing: $20 \mathrm{~cm} \times 10 \mathrm{~cm}$

\subsubsection{Intercultural operation}

Weeding and pulverizing of soil were done regularly whenever necessary to keep the plots free from weeds and to ensure good aeration in soil.

\subsubsection{Plant protection}

Ridomil MZ 72 WP and Rovral at the rate of 25g and 45g in 10 litre of water was applied at an interval of 15 days from 30 DAP up to one month before harvesting to prevent the purple leaf blotch disease caused by Alternaria porii.

\subsubsection{Harvesting}

The garlic plants when the tops turn yellowish or light brownish and show signs of drying up indicate the symptom of maturity. The bulbs were lifted, freed from earth and the leaves were tied at the top. The bulbs were cured for 2 to 3 days in the shade before storing them in an ordinary room. Thoroughly cured garlic bulbs store well in ordinary well-ventilated room/store. 
At the experimental site, a laboratory for weighing and sample drying was used. A good electrical weighing balance and oven were used.

\subsubsection{Collection of data}

The following data were recorded on the base of physio- morphological growth parameters after planting as well as on yield.

\subsection{1 Number of leaves per plant}

The number of leaves per plant was counted from 5 randomly selected plants. The mean number of leaves was calculated by dividing total number of leaves observed from 5 plants by 5 .

\subsubsection{Height of plant $(\mathrm{cm})$}

Plant height was measured from the base of the leaf sheath to the tip of the longest leaf of 5 randomly selected plants and mean was calculated in cm.

\subsubsection{Length of leaf $(\mathrm{cm})$}

Length of leaf was measured from the base to top of the leaf of 5 randomly selected leaves in centimeter and mean was calculated.

\subsubsection{Fresh leaf weight (g)}

Fresh weight of leaves of 5 randomly selected plants was taken and their average was calculated in gram as fresh weight of leaves of individual plant.

\subsubsection{Dry leaf weight (g)}

Fresh weight of leaves of 5 randomly selected plants was taken and the average was considered in gram as fresh weight of leaves per plant. The leaves were cut into small pieces, dried in the sun for 3 days and kept in an oven at $80^{\circ} \mathrm{C}$ for 72 hours, till a constant weight was achieved. Average dry weight of leaves per five plants was estimated.

\subsubsection{Number of clove/plant}

The cloves were counted from 5 plants and their average was taken as a number of cloves per plant.

\subsubsection{Bulb diameter $(\mathrm{cm})$}

Diameter at the widest part of 5 randomly selected bulbs was measured in centimeter and then average diameter of each bulb was calculated.

\subsubsection{Fresh weight of bulb $(\mathrm{g})$}

Fresh weight of bulb of 5 randomly selected plants was taken and their average was calculated in gram as fresh weight of bulb of individual plant.

\subsubsection{Dry weight of bulb (g)}

Fresh weight of bulb of 5 randomly selected plants was taken, and the average was considered in gram as fresh weight of bulb per plant. Bulbs were cut into small pieces, dried in the sun for 3 days and kept in an oven at $80^{\circ} \mathrm{C}$ for 72 hours, till a constant weight was achieved. Average dry weight of bulb per plant was estimated.

\subsubsection{Yield of bulb per plot $(\mathrm{kg})$}

The yield of bulb per plot was taken in kilogram $(\mathrm{kg})$ by harvesting all the bulbs of each plot after removing the roots and pseudo stem.

\subsubsection{Yield of bulb per hectare $(t)$}

Per plot yield of bulb was converted into yield per hectare and expressed in ton $(\mathrm{t})$.

\subsubsection{Design and layout of the experiment}

The experiment was laid out in a Randomized Completely Block Design (RCBD) with three replications. The whole plot was divided into three blocks, each containing 25 unit plots of 1 square meter and one germplasm represented one treatment.

\subsubsection{Statistical analysis}

Data collected from the experiment were statistically analyzed as per design of the experiment followed in the field using PLABSTAT computer package programmer [30-34]. The means for all treatments were calculated and the analyses of variances for all the characters under consideration were performed by ' $F$ ' variance test. The significance of difference between pair of means was performed by Least Significant Difference (LSD) test taking 5\% probability level as the minimum unit of significance [5].

\subsubsection{Estimation of simple correlation coefficients}

Simple correlation coefficients were calculated using PLABSTAT software version $2 \mathrm{~N}$ by the following formula [6]:

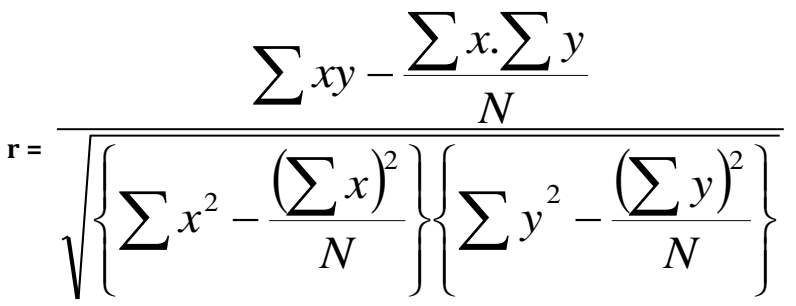

Where,

$\Sigma=$ Summations

$\mathrm{X}$ and $\mathrm{Y}$ two variables correlated

$\mathrm{N}=$ Number of observation.

Results and Discussion

\subsection{Results}

A wide range of variation was observed among germplasm on number of leaves, height of plant, leaf length, number of cloves per bulb, length and diameter of bulb, yield per plot and yield of garlic during the growth period as well as at final harvest. 
Morphological characters of different garlic germplasm: There were significant differences in the number of leaves per plant. The highest number of leaves (10.63) was obtained from germplasm G49. On the other hand, the lowest number of leaves (4.70) was recorded from germplasm G8 followed by G10 (5.03), G35 (5.20) and G32 (5.40). It was observed that germplasm G29 produced the tallest plant (74.60 cm) followed by G2 (66.50 cm) and G1 (66.17 $\mathrm{cm})$. The shortest plant was found in the germplasm G13 $(39.17 \mathrm{~cm})$. Significant differences were also observed in length of leaf. The highest length of leaves $(43.57 \mathrm{~cm})$ was obtained from germplasm G49 followed by G29 $(41.27 \mathrm{~cm})$. On the other hand the lowest length of leaves (23.97 $\mathrm{cm})$ was recorded from germplasm G10 followed by G38 $(26.63 \mathrm{~cm})$ and G13 $(27.60 \mathrm{~cm})$. Remarkable variations were observed on fresh leaf weight. The highest fresh leaf weight (92.47) was obtained from germplasm G49 followed by G38 (85.50), G53 (74.73) and G8 (67.80) gm. On the other hand, the lowest fresh leaf weight (21.17) was recorded from germplasm G32. Germplasm G49 produced the highest amount of dry leaf weight (6.13g). The lowest amount of dry leaf weight was found in germplasm G10 (2.57g) (Table 1).

Table 1: Morphological characters of different garlic germplasm.

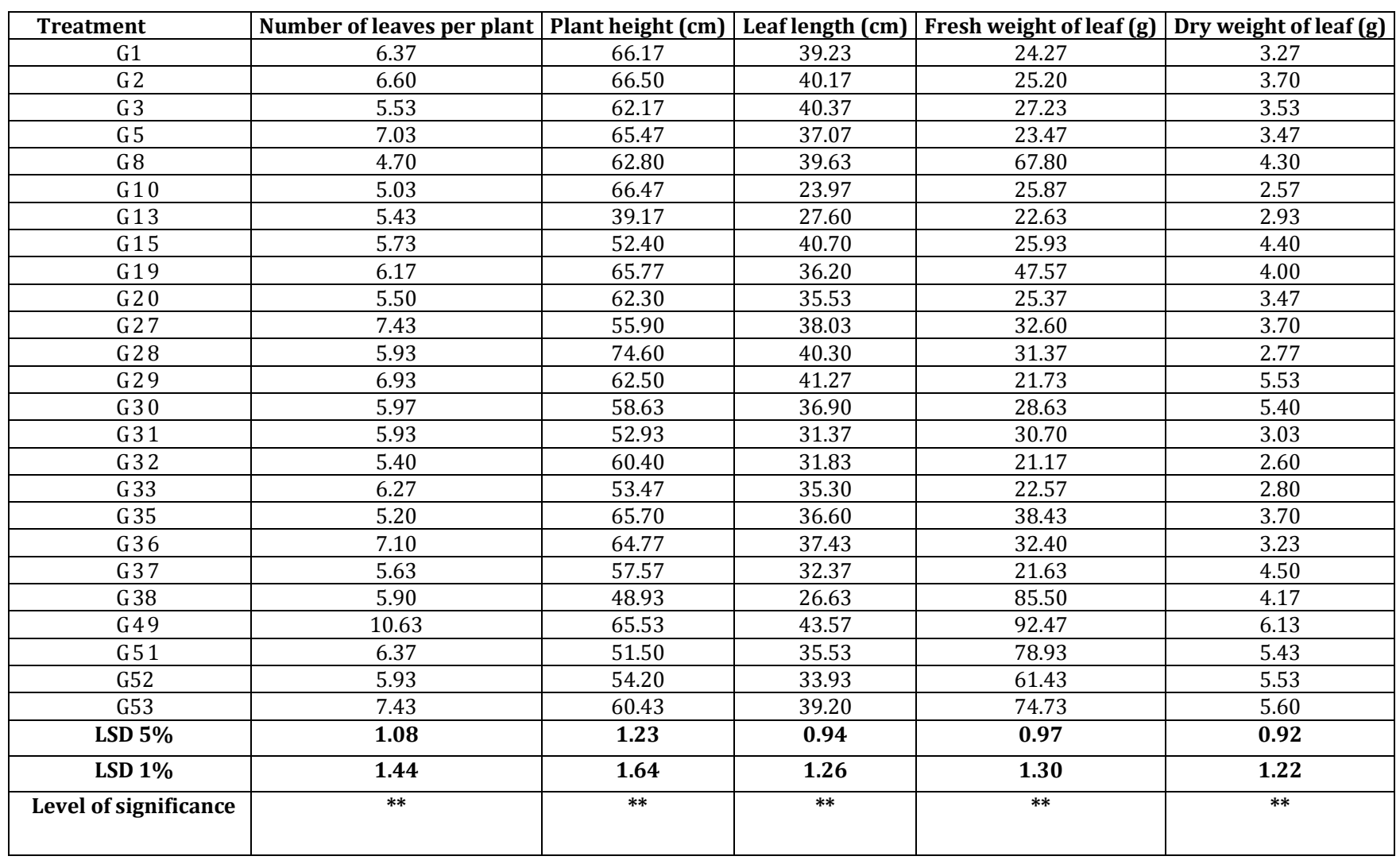

** = Significant at $1 \%$ level of probability, G1-G53 are the garlic germplasm.

\subsection{Yield and yield contributing characters of different garlic germplasm}

Number of cloves showed per plant significant differences among them. The highest number of cloves (42.13) was recorded from germplasm G49. On the other hand, the lowest number of cloves was observed from G36 (17.57). Highly significant differences were observed in bulb diameter also. Among bulb diameters G49 $(4.13 \mathrm{~cm})$ was recorded the highest. On the other hand, G38 $(2.73 \mathrm{~cm})$ performed the lowest. It was observed that germplasm G49 produced the highest amount of fresh weight of bulb (21.37 g) and the lowest amount of fresh weight of bulb was found in germplasm G38 (11.83 g) followed by G51 (12.53 g) and G20 (12.70g). Maximum dry weight of bulb was obtained from G49 (5.73 g) which was significantly different from others and followed by G27 (5.10 g). Minimum dry weight of bulb was obtained from G38 (2.87 g) followed by G52 (2.93 g). Highly significant differen ces were observed in yield of bulb per plot. The germplasm G49 (0.983 kg) produced highest yield per plot whereas the lowest (0.524 kg) was from G13. The yield of garlic per plot was converted into per hectare and was expressed in tons. Yield per hectare of different germplasm showed highly significant variations. Germplasm G49 gave the highest ( $9.83 \mathrm{t} / \mathrm{ha}$ ) yield followed by germplasm G53 (8.32 t/ha). The lowest yield (5.24 t/ha) was obtained from germplasm G13 (Table 2).

Table 2: Yield and yield contributing characters of different garlic germplasm.

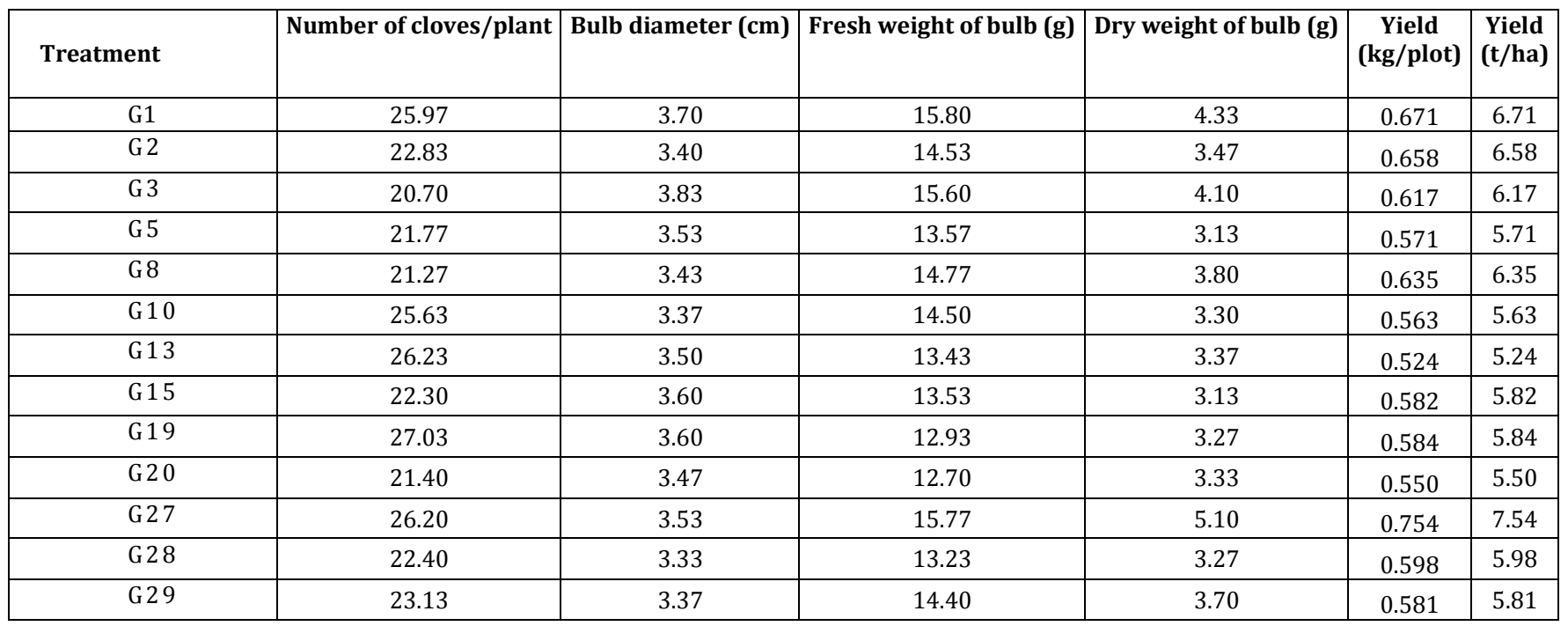




\begin{tabular}{|c|c|c|c|c|c|c|}
\hline Treatment & Number of cloves/plant & Bulb diameter (cm) & Fresh weight of bulb (g) & Dry weight of bulb (g) & $\begin{array}{c}\text { Yield } \\
\text { (kg/plot) }\end{array}$ & $\begin{array}{l}\text { Yield } \\
\text { (t/ha) }\end{array}$ \\
\hline G30 & 20.70 & 3.47 & 13.53 & 3.30 & 0.621 & 6.21 \\
\hline G3 1 & 20.83 & 3.07 & 12.97 & 3.57 & 0.576 & 5.76 \\
\hline G32 & 21.57 & 3.37 & 14.57 & 3.77 & 0.632 & 6.32 \\
\hline G33 & 22.10 & 3.40 & 13.60 & 3.27 & 0.584 & 5.84 \\
\hline G35 & 18.27 & 3.07 & 12.93 & 3.27 & 0.594 & 5.94 \\
\hline G36 & 17.57 & 3.03 & 13.23 & 3.37 & 0.567 & 5.67 \\
\hline G3 7 & 23.57 & 3.50 & 13.87 & 3.87 & 0.665 & 6.65 \\
\hline G38 & 25.53 & 2.73 & 11.83 & 2.87 & 0.552 & 5.52 \\
\hline G49 & 42.13 & 4.13 & 21.37 & 5.73 & 0.983 & 9.83 \\
\hline G51 & 27.37 & 3.40 & 12.53 & 3.13 & 0.574 & 5.74 \\
\hline G52 & 18.20 & 3.27 & 13.43 & 2.93 & 0.631 & 6.31 \\
\hline G53 & 19.43 & 3.87 & 18.23 & 4.43 & 0.832 & 8.32 \\
\hline LSD 5\% & 1.11 & 1.03 & 1.27 & 0.68 & 0.01 & 0.18 \\
\hline LSD 1\% & 1.47 & 1.38 & 1.69 & 0.91 & 0.02 & 0.24 \\
\hline Level of significance & $* *$ & $* *$ & $* *$ & $* *$ & $* *$ & $* *$ \\
\hline
\end{tabular}

** = Significant at $1 \%$ level of probability, 1 Plot size $=1 \mathrm{~m} 2$

Different germplasm resulted better performance in respect of height of plant, number of leaves per plant, fresh weight of bulb, total number of cloves per bulb and yield in ton per hectare. Germplasm G49 from Vietnam gave the highest results in almost all the mentioned parameters. This might be due to the fact that germplasm G49 had a good genetic potential which enhanced more cell division and cell elongation resulting the best performance. A study reported that the maximum plant height $(60.47 \mathrm{~cm})$, maximum yield per plot $(7.57 \mathrm{~kg})$ and the maximum number of leaves per plant (14.60) [7]. Some researchers found in their research the greatest bulb diameter $(3.26$ and $3.23 \mathrm{~cm}$ ) [8]. A scientist also reported about the bulb diameter which varied from 66 to $70 \mathrm{~cm}$ [9]. These investigations are more or less support with the present findings.

\subsection{Coefficients of correlation for morphological characters}

The estimated simple correlation coefficients were made among different morphological characteristics of garlic germplasm in all possible one way paired combinations. Number of leaves per plant was not significantly and positively correlated with plant height $(\mathrm{r}=0.171)$. Whereas leaf length $\left(\mathrm{r}=0.489^{*}\right)$, fresh weight of leaf $\left(r=0.406^{*}\right)$ and dry weight of leaf $\left(r=0.460^{*}\right)$ showed significant positive correlation. Plant height showed significant positive correlation with leaf length $\left(r=0.480^{*}\right)$. On the other hand, fresh weight of leaf $(r=-0.112)$ and dry weight of leaf $(r=-0.150)$ showed non-significant negative correlation. Leaf length was not significantly and positively correlated with fresh weight of leaf $(r=0.084)$ and dry leaf weight $(r=0.322)$. Fresh weight of leaf showed highly significant positive correlation with dry weight of leaf $\left(\mathrm{r}=0.689^{* *}\right)$ which indicated that with the increase of fresh weight of leaf those dry weight of leaf would be increased (Table 3).

Table 3: Coefficients of correlation for morphological characters of different garlic germplasm

\begin{tabular}{l|c|c|c|c}
\hline Character s & Number of leaves per plant & Plant height (cm) & Leaf length (cm) & Fresh weight of leaf (g) \\
& & & & \\
\hline Plant height (cm) & 0.171 & $0.480^{*}$ & \\
Leaf length (cm) & $0.489^{*}$ & -0.112 & 0.084 \\
Fresh weight of leaf (g) & $0.406^{*}$ & -0.150 & 0.322 & $0.689^{* *}$ \\
Dry weight of leaf (g) & $0.460^{*}$ & & \\
\hline
\end{tabular}

* Significant at $5 \%$ level of probability, ${ }^{* *}$ Significant at $1 \%$ level of probability

\subsection{Coefficients of correlation for yield and yield contributing characters of different garlic germplasm}

Highly significant positive correlation was observed in number of cloves per plant with bulb diameter $\left(r=0.539^{* *}\right)$, fresh weight of bulb $(r=0.567 * *)$, dry weight of bulb $\left(\mathrm{r}=0.574^{* *}\right)$, yield per plot $\left(\mathrm{r}=0.554^{* *}\right)$ and yield per hector $\left(\mathrm{r}=0.554^{* *}\right)$ which indicated that with the increase in number cloves per plant those bulb diameter, fresh weight of bulb, dry weight of bulb, yield per plot and yield per hectare would be increased. Bulb diameter also showed highly significant positive correlation with fresh weight of bulb $\left(r=0.785^{* *}\right)$, dry weight of bulb $\left(r=0.685^{* *}\right)$, yield per plot $\left(r=0.679^{* *}\right)$ and yield per hectare $\left(r=0.679^{* *}\right)$. Fresh weight of bulb showed highly significant and positive correlation with dry weight of bulb $\left(r=0.896^{* *}\right)$, yield per plot $(r=$ $\left.0.926^{* *}\right)$ and yield per hectare $\left(r=0.926^{* *}\right)$. Highly significant positive correlation was observed in dry weight of bulb with yield per plot $\left(r=0.875^{* *}\right)$ and yield per hectare $\left(\mathrm{r}=0.875^{* *}\right)$ which indicated that with the increase in dry weight of bulb those yield per plot and yield per hectare would be increased. Yield of bulb per plot showed highly significant and positive correlation with yield per hectare $\left(r=1.000^{* *}\right)$ that means with increasing in yield per plot with the increasing in yield per hectare (Table 4).

Table 4: Coefficients of correlation for yield and yield contributing characters of different garlic germplasm

\begin{tabular}{l|l|l|l|l|l}
\hline Characters & Number of cloves/plant & $\begin{array}{l}\text { Bulb diameter } \\
\text { (cm) }\end{array}$ & $\begin{array}{l}\text { Fresh weight } \\
\text { of bulb (g) }\end{array}$ & $\begin{array}{l}\text { Dry weight } \\
\text { of bulb (g) }\end{array}$ & $\begin{array}{l}\text { Yield (kg/plot) } \\
\text { Bulb diameter (cm) }\end{array}$ \\
Fresh weight of bulb (g) & $0.539^{* *}$ & $0.567^{* *}$
\end{tabular}




\begin{tabular}{|c|c|c|c|c|c|}
\hline Dry weight of bulb (g) & $0.574^{* *}$ & $0.685^{* *}$ & $0.896^{* *}$ & & \\
\hline Yield (kg/plot) & $0.554^{* *}$ & $0.679^{* *}$ & $0.926^{* *}$ & $0.875^{* *}$ & \\
\hline Yield (ton/ha) & $0.554^{* *}$ & $0.679^{* *}$ & $0.926^{* *}$ & $0.875^{* *}$ & $1.000^{* *}$ \\
\hline
\end{tabular}

** Significant at $1 \%$ level of probability

\section{References}

[1] J.W. Purseglove, “Tropical crops:Monocotyledons”, ELBS Longman, London. pp. 52-56, 1975.

[2] BBS. "Monthly Stastical Bulletin, October 2004”, Bangladesh Bureau of Statistics, Statistics Divition, Ministry of Planning, Government of Peoples Republic of Bangladesh. Dhaka., p.57, 2007.

[3] FAO. "Production Yearbook 2007", Food and Agriculture Organization of the United Nations, Rome, Italy., Vol. 57, $177,2007$.

[4] UNDP. Land Resource Appraisal of Bangladesh for Agril. Dev. Report 2. Agro-ecological Region of Bangladesh. FA0, Rome, Italy. Pp. 577, 1998.

[5] K.A. Gomez, and A.A. Gomez, “Statistical Procedures for Agricultural Research. (2nd ed.)”, A Wiley International Science Publication, John Wiley Sons, New York. 680 p, 1984.

[6] H.F. Utz, PLABSTAT (Version 2N). A computer program for the computation of variance and covariances. Institute of Plant Breeding. Seed Science, and Population Genetics, University of Hohenheim, Stuttgart, 2007.

[7] M.N. Shigwedha, B.N. Korla, and Y.R. Shukla. "Evaluation of garlic clones for morphological characters and yield”, Annals of Agri. Bio. Res., Vol. 14(2): $149-152,2009$

[8] R.P. Gupta, R.C. Sharma, S.R. Bhonde, and D.K. Singh, "Studies on the yield and storage performance of garlic (Allium sativum L.) in relation to planting time and clove size", Newsletter National Horticultural Research and Development Foundation, Vol. 23(4), 17-22, 2003.

[9] G.T. Avila, "Study of parameters to determine the opportune moment for harvest of "white" garlic (Allium sativumL.)", Horticultura Argentina, Vol. 19(47), 28-39, 2000.

[10] D.I. Adekpe, J.A.Y. Shebayan, U.F. Chiezey, and S. Miko, "Yield responses of garlic (Allium sativum L.) to oxadiazon, date of planting and intra-row spacing under irrigation at Kadawa, Nigeria”, Crop Prot., Vol. 26 (12),1785-1789, 2007.

[11] H.G. Ahmed, M.D. Magaji, A.I. Yakutu, L. Aliyu, and A. Singh, "Response of garlic (Allium sativum L.) to irrigation interval and clove size in semi-arid, Nigeria", J.Plant Sci., Vol. 2, 202-208, 2007.

[12] B. Al-Safadi, M.I.E. Arabi, and Z. Ayyoubi, "Differences in quantitative and qualitative aracteristics of local and introduced cultivars and mutated lines of garlic", J. Veg. Crop Prod., Vol. 9(1), 21-31, 2003.

[13] J.A. Arguello, L.R. Falcon, L. Seisdedos, S. Milrad, and R. Bottini, "Morphological changes in garlic (Allium sativum L.) microbulblets during dormancy and sprouting as related to peroxidase activity and gibberellin content", Biocell., 25(1): 1-9, 2001.

[14] K. Baghalian, N.M. Reza, Z.S. Ali, and H.A. Naghdi Badi, N. Mohammad, "Post-planting evaluation of morphological characters and allicin content in Iranian garlic (Allium sativum L.) ecotypes”, Acta Hort., Vol. 107(4), 405, 2005.

[15] K. Baghalian, M.R. Sanei, M.R. Naghavi, A. Khalighi, and H.A. Naghdi Badi, "Post-culture evaluation of morphological divergence in Iranian garlic ecotypes", Acta Hort., Vol. 107(4), 688, 2006.

[16] P.S. Brar, and S.P.S. Gill, "Effect of clove size on yield of garlic", Haryana J. Hort. Sci., Vol. 29 (1/2), 129, 2000.

[17] P.K. Chand Subrata, Chattopadhyay, and M.A. Hasan, “Dynamics of growth and yield of garlic in variable planting time and applied nutrients”, Indian J. Hort., Vol. 67(3), 201, 2010.

[18] N.B. Dhakulkar, S.M. Ghawade, and S.R. Dalal, "Effect of spacing and clove size on growth and yield of garlic under Akola conditions", Int. J. Agri. Sci., Vol. 5 (1), 261-262, 2009.

[19] J. Dyduch, and A. Najda, "Influence of shape of air bulbils of winter garlic (Allium sativum L.) on the morphological features and quality of plants", Horticultura, 9(Supplementum): 295-299, 2001.

[20] J. Dyduch, and A. Najda, “The dependence on the number of air bulbils in the maternal umbel of winter garlic (Allium sativum L.) and morphological features and quality of grown up plants", Acta Scientiarum Polonorum Hortorum Cultus, Vol. 2(1), 13-19, 2003.

[21] T. Etoh, and P.W. Simon, “Diversity, fertility and seed production of garlic”, Allium crop science. Recent Adv., Vol. 4(5), 101-117, 2002.

[22] G. Figliuolo, and D. Stefano, “Is single bulb producing garlic Allium sativum or Allium ampeloprasum?”, Scientia Hort., Vol. 114(4), $243-249,2007$.

[23] G. Fikreyohannes, W. Kebede, D. Nigussie, and T. Akhilesh, "Effects of clove size and plant density on the bulb yield and yield components of Ethiopian garlic (Allium sativum L.)", 2005.

[24] C. Jeong-Jin, O. Choong, H.O. Sook, K.C. Guk, K.S. Yeol, and K.W. Bae, "Food value and postharvest physiological characteristics of wild garlic in Korea", Korean J. Hort. Sci. Tech., Vol. 23(2), 164-169, 2005.

[25] KC, R.B. “Characterization and evaluation of indigenous garlic (Allium sativum L.) germplasms of Nepal”, M.Sc. Thesis, Department of Horticulture, IAAS, Rampur, Chitwan, Nepal. pp. 103, 2002.

[26] B. Kambiz, R.N. Mohammad, A.Z. Seyed, N.B. Hassanali, "Post-planting evaluation of morphological characters and allicin content in Iranian garlic (Allium sativum L.) ecotypes", Scientia Hort., Vol. 107(4), 405- 410, 2006.

[27] T. Mahmood, S.I. Hussain, K.M. Khokhar, M.H. Bhatti, and H. Laghari, “Comparative performance of garlic cultivars”, Asian J. Plant Sci., Vol. 1, 160-161, 2002.

[28] D.R. Panthee, H.N. Regmi, P. P. Subed, S. Bhattaharai, and J. Dhakal, “Diversity analysis of garlic (Allium sativum L.) germplasms available in Nepal based on morphological characters", Genetic Resources and Crop Evolution, Vol. 53, 205-211, 2006.

[29] M.R. Pooler, and P.W. Simon, "Characterization and classification of isozyme and morphological variation in a diverse collection of garlic clones", 
Euphytica, Vol. 68,121-130, 1993.

[30] Y. Singh, and R. Chand, "Performance studies of some garlic (Allium sativum L.) clones”, Himachal J. Agri. Res., Vol. 29 (1\&2), $35-42,2003$.

[31] P. Xu, J. Zou, Q. Meng, J. Zou, W. Jiang, and D. Liu, “Effects of Cd (2+) on seedling growth of garlic (Allium sativum L.) and selected physiological and biochemical characters”, Bioresour Tech., 99(14):6372-8, 2008.

[32] Y.F. Juan, L.S. Qi, and W.X. Feng, "Effects of boron in soil on the physiological-biochemical characteristics, yield and quality of garlic", Scientia Agricultura Sinica., Vol. 38(5), 1011-1016, 2005.

[33] B. Zahedi, A.K. Kashi, Z. Zamani, G.H. Mosahebi, and M. Hassani, "Evaluation of Iranian Garlic (Allium sativum L.) Genotypes Using Multivariate Analysis Methods Based on Morphological Characteristics", Biotech., Vol. 6(3), 353-356, 2007.

[34] B. Zuraw, “Biological value and morphological traits of pollen of selected garlic species Allium L”, Acta Agrobotanica, Vol. 60(1), 67-71, 2007.

[35] R.P. Gupta, “Garlic cultivation technology”, Indian J. Arecanut Spices and Medicinal Plants, Vol. 9(1), 1-9, 2007. 